Journal of the Scholarship of Teaching and Learning, Vol. 20, No. 2, October 2020, pp. 127-142.

doi: 10.14434/josotl.v20i2.25679

\title{
Valuing the Engaged Work of the Professoriate: Reflections on Ernest Boyer's Scholarship Reconsidered
}

\author{
Lauren Wendling \\ Indiana University \\ lwendlin@iu.edu
}

\begin{abstract}
This article discusses faculty engaged teaching and research as an imperative function of the academic institution in the $21^{\text {st }}$ century. Reflecting on Ernest Boyer's Scholarship Reconsidered, this article traces the history of the public nature of higher education and its role within institutions today and discusses the crucial role of promotion and tenure in advancing the engaged work of faculty.
\end{abstract}

\section{Keywords: Ernest Boyer, engaged teaching, engaged scholarship, promotion and tenure}

Though the roots of higher education's involvement in society have long run deep, many fear that in the last few years, as the American social and political landscape has become increasingly more polarized and volatile, institutions of higher education have strayed away from their primary missions to advance the public good and have become more isolated from the communities in which they are situated. This is evidenced by the fact that while $95 \%$ of urban research institutions have made a commitment to community engagement in their most recent strategic plans, only $55 \%$ of Americans today believe that higher education has a positive impact on their communities (Accardi, 2018). This growing concern is influenced by multiple forces including, but not limited to, the distortion of institutional missions, growing tuition costs and student loan debt, and a general feeling of incongruency between social expectations and institutional goals (Chambers, 2005; Cohen, 1998; Giroux, 2003; Lynton, 1995; Rice, Saltmarsh, \& Plater, 2015; Wade \& Demb, 2009; Ward, 2003). Acknowledging this current moment in history that is highly politically charged and where the mission of American higher education is becoming increasingly more questioned by the public, this article seeks to highlight engaged teaching and scholarship as essential forms of faculty work that must be encouraged and rewarded within the academy.

\section{Community Engagement and the Public Good}

It is first important to note that the notion of the public good can be quite vague and open to interpretation. A sound argument can be made that any teaching and/or scholarship of university faculty in some way seeks to benefit the public, as has historically been the mission of American higher education (Lucas, 2006; Thelin, 2004). While this article does not attempt to dispute that claim, focus here is given to the recognition and reward of faculty whose teaching and scholarship engages with the public in specific and intentional ways. This article utilizes the Carnegie Foundation's definition of community engagement to define the type of faculty work that is here understood as engaged. The Carnegie Foundation defines engagement as "collaboration between institutions of higher education and their larger communities (local, regional/state, national, global) for the mutually beneficial exchange of knowledge and resources in a context of partnership and reciprocity" (Brown University, 2018). With this understanding, faculty who pursue engaged teaching and research bring with them to their work a moral responsibility to not only apply their practice and scholarship to address social problems and community concerns, but to do so in conjunction with community (Deetz, 2008; Liang, Sandmann, \& Jaeger, 2015). While it is essential to define what is meant by the term engagement, it is 
also important to briefly explore and elaborate on the notion of the public good. For this, we turn to John Dewey and Jurgen Habermas.

\section{The Public Good and the Role of the Expert}

In The Public and its Problems, Dewey (1927) defined the public good as both the virtue that we as a society seek to improve our wellbeing, and the group of individuals that does the seeking. Participating in the public sphere educates both individual citizens and the collective knowledge of society, which are foundational requirements for a successful and thriving democracy (Dewey, 1927). Further, participation in the public sphere, Dewey (1927) argued, is essential for addressing an asymmetry between the ability for a small group of individuals to make decisions negatively affecting large groups of people. Due to the, at times, deeply destructive actions of the few, participation in the public sphere is a necessary action to care for and prevent systemically volatile disruptions to the public good (Dewey, 1927).

Both Dewey (1927) and Habermas (1989) believed individuals' participation in society is essential to ensuring an appropriate balance between individuals, organizations, and the state. In order to cultivate a successful democracy, citizens must actively engage with each other and societal institutions, and make collective choices about their wellbeing. Both Dewey and Habermas called citizens to actively participate in the public sphere while recognizing the unique role of the expert. Dewey (1927) ultimately concluded that the role of experts is to generate and disseminate what he called social knowledge. The experts, most notably university academics and intellectuals, must lead individuals' participation in critical debate, encourage positive change in their communities, and promote social discourse (Habermas, 1989). Writing in the mid-20 ${ }^{\text {th }}$ century, both Dewey and Habermas' words ring true today.

However, even though the modern era has brought about new advancements to increase participation in the public sphere, (e.g. globalization, technology, etc.), many believe public discourse and democratic participation of the expert has diminished. Russell Jacoby (1987) argued that even with such advancements, society's experts who once worked in and with the public now flock to the ivory towers, converse only with other academics, and are primarily concerned with achieving tenure, which has led to diminished public discourse and action. This, then, begs the question to universities and the academics they employ, What role does the university and its faculty play in not only informing the public more directly, but guiding their inquiry by the public's perceived needs?. Further, How are our universities rewarding, or failing to reward, those that do?

\section{Engaged Teaching and Research}

It is safe to assume that both Dewey and Habermas would argue that at its core, faculty teaching and research must be fundamentally responsive to the needs of community and the community's desired degree of collaboration. Highlighting community and institutional reciprocity, faculty engagement should underscore mutually beneficial partnerships that produce co-created solutions and advance the public good (Liang et al., 2015; O’Meara, 1997). Further, the concept of reciprocity and the two-way dimension of engaged academic work differentiate engaged teaching and research from traditional, more isolated forms of work where institutional and faculty resources extended in only one direction - from the institution to the community (Sandmann, 2008). The bidirectional approach to engaged teaching and scholarship is one of its foundational concepts, highlighting the unique characteristics of this form of faculty work. Lastly, an additional distinction between traditional faculty and faculty whose teaching and research is engaged in community is the type of created outputs. While traditional faculty tend to focus on knowledge production, advancement, and the dissemination of their work to

Journal of the Scholarship of Teaching and Learning, Vol. 20, No. 2, October 2020. josotl.indiana.edu 
a highly academic audience - which undoubtedly may benefit the larger society, engaged faculty seek social change, equitable justice, and local improvement that often produces outputs for a communitybased audience (Strand, Marullo, Cutforth, Stoecker, \& Donohue, 2003; Ward, 2005).

\section{A Brief History of Higher Education and Community Engagement}

There is a longstanding historical tradition for institutions of higher education and their faculty to connect their teaching and research to the advancement of society. For over 350 years, higher education has been "inextricably interlocked" with the larger purposes of American society and the advancement of public interest (Boyer, 1996, p. 19). It is thus understandable that for institutions of higher education, advancement of the public good is deeply rooted in the foundational principles of American education (Liang et al., 2015).

As Boyer (1990) noted, "American higher education has never been static" (p. 81). Throughout its history, higher education has shaped its programs, curriculum, and research in response to the ever-changing American society. The history of public advancement in higher education dates back to the creation of the institution of higher learning in the $17^{\text {th }}$ century. The application of knowledge for the advancement of the common good has served as a fundamental principle of American education and is illustrated in the colonial colleges' mission to prepare men to serve as religious, political, and civic leaders (Rudolph, 1977; Veysey, 1965). As the United States continued to grow and adapt, so too did the academy. The 1824 founding of Rensselaer Polytechnic Institute served as a constant reminder that higher education must adapt to assist the nation with creating men able to build railroads, bridges, and national infrastructure (Rudolph, 1977). Institutions' social responsiveness to the needs of a growing country with the 1862 Morrill Act and 1887 Hatch Act illustrated higher education's commitment to placing education in the hands of the "common people" and bringing agricultural and mechanical learning to the farmer (Boyer, 1990, p. 10).

However, over the years, the "expert model of knowledge delivery" and professionalization of the professoriate came to dominate the discourse of higher education and seriously affect the relationship between the academy and society (Deetz, 2008; Liang et al., 2015, p. 233). In the early $20^{\text {th }}$ century, American higher education became a contested field, as institutions were criticized for being "intellectually flabby", neglectful of social needs, and confined to the ivory tower where resources and time were poured solely into research and publication (Boyer, 2014, p. 10). However, as the nation entered into the mid- $20^{\text {th }}$ century and the second World War, demands for the reorientation of higher education to serve the national interest grew more insurgent. As a period of panic set in after the Soviet launch of Sputnik in 1957, the National Defense Education Act of 1958 poured millions of dollars into higher education to increase the study of science, math, and foreign languages (Boyer, 2014).

By the late 1970s and early 1980s, the climate of higher education changed again, as Ronald Regan took office and an era of conservatism swept the United States. The country witnessed the booming industrial economies of Japan and other Asian nations while facing declining test scores at home (Ravitch, 1990). This served as the impetus for the appointment of the National Commission on Excellence in Education in 1981 (Ravitch, 1990). Tasked with examining the quality of education in the United States, the commission produced $A$ Nation at Risk, which quickly became the iconic educational statement of the 1980s (Ravitch, 1990). A Nation at Risk, which called for a more rigorous assessment of teaching and learning, provided the nation a "much-needed jolt" and emphasized the previously understood belief that American society could not prosper if schools, colleges, and universities were not responsive to the needs of society (Boyer, 2014; Ravitch, 1990). Expanding upon A Nation at Risk, in 1985 Frank Newman and the Carnegie Foundation published The Newman Report $I$ and $I I$ which examined the different ways that institutions of higher education could "assume

Journal of the Scholarship of Teaching and Learning, Vol. 20, No. 2, October 2020. josotl.indiana.edu 
expanded responsibilities in national renewal" (Newman, 1985, p. 1). The Reports urged colleges and

universities to address the issue of civic involvement and responsibility among its faculty and staff (Newman, 1985).

As a result of the increasing focus on the relationship between higher education and American society, a handful of scholars, activists, and strategists weighing in on the relationship between higher education and society rose to national prominence. Ernest Boyer, then-President of the Carnegie Foundation for the Advancement of Teaching became one of the most prominent voices of the movement for educational reform (Boyer, 2014; Ravitch, 1990). His groundbreaking 1990 work Scholarship Reconsidered: Priorities of the Professoriate examined faculty priorities and asked institutions of higher education to place teaching and scholarship in the larger context of American society and urged institutions to recognize and reward faculty work that works in and with community.

Though the advancement of the public good has always been a fundamental mission of American higher education, the relationship between colleges, universities, and the general public is complex and has been, at times, highly ambiguous. While the work of faculty has historically impacted broader society in a variety of positive ways, the levels of impact and methods of faculty engagement with society are diverse and many. It is thus important to note that Boyer's 1990 critique of institutional engagement in Scholarship Reconsidered was not lamenting the impact of faculty's work on the broader society, but rather was critical of the priority institutions were giving specific forms of faculty work that were typically done in isolation, removed from community, with little importance placed on the concepts of mutual benefit and reciprocity.

\section{The Life and Impact of Ernest Boyer}

The work of Ernest Boyer profoundly affected the role, nature, and direction of higher education in the late $20^{\text {th }}$ century and continues to have consequence on the intellectual, social, and civic life of the academy today. In 1979, Boyer began his service as President of the Carnegie Foundation for the Advancement of Teaching, where he remained until his death in 1995 (Hill, 2010). As is well known, the policies and direction of The Carnegie Foundation have historically reflected the personality and interests of its leadership - standing for academic rigor and high academic standards (Boyer, 2014). Boyer, who was known for his "infectious optimism" regarding the ability of education to advance both individuals and American society, approached higher education primarily through the lens of service and connectedness (Hill, 2010, p. 2).

\section{Scholarship Reconsidered}

Boyer is most known for his perspectives on faculty engagement and the belief that faculty scholarship involves not only the scholarship of discovery, but also teaching and learning, integration, and application (Boyer, 1990; 1996). Recognizing multiple approaches to academic work, Boyer advocated for faculty to commit to conducting teaching and research that seeks first to address problems in society and pursues channels of dissemination that allow for a direct contribution and implementation by community (Boyer, 1990).

In 1990 Boyer and the Carnegie Foundation for the Advancement of Teaching released Scholarship Reconsidered: Priorities of the Professoriate. Even though it was a small book of less than 100 pages, it sparked a revolutionary change in how institutions of higher education would view the role of faculty, engagement, and community. Boyer produced nine reports during his time at Carnegie by far the most influential and controversial of the nine was Scholarship Reconsidered, due to its critique of the prioritization of certain forms of faculty scholarship and teaching as well as the traditional structures built into institutions to reward faculty work (Boyer, 2014). Criticizing institutions that only

Journal of the Scholarship of Teaching and Learning, Vol. 20, No. 2, October 2020. josotl.indiana.edu 
rewarded, both monetarily and through promotion and tenure, teaching and research that were disengaged from community and disseminated scholarly outputs in traditional academic channels that are not widely available for public consumption, Boyer advocated for institutional change in the late $20^{\text {th }}$ century (Boyer, 2014).

Scholarship Reconsidered is based upon a 1989 Carnegie Foundation survey that evaluated the responses of over five thousand American scholars who were asked about the role of the professoriate (Hill, 2010). For Boyer, the lack of responses detailing the civic role of faculty spurred him to produce a manifesto acknowledging "what it means to be a scholar" (Boyer, 1990, p. 2). One of its central themes rested upon outlining the role of the scholar in today's world and how the academy prioritizes certain objectives through the faculty reward system. Boyer (1990) emphasized:

The time has come to step back and reflect on the variety of functions academics are expected to perform. It's time to ask how priorities of the professoriate relate to the faculty reward system, as well as to the missions of America's higher learning institutions. Such an inquiry into the work of faculty is essential if students are to be well served, if the creativity of all faculty is to be fully tapped, and if the goals of every college and university are to be appropriately defined. (p. 2)

Boyer sought to classify quality teaching and research as social application and connect them to the essential definition of faculty work. Teaching and research that works in and with community, he reasoned, should be directly tied to one's field of study and, using one's advanced scholarly knowledge, work in conjunction with local communities to advance shared institutional and public goals (Boyer, 1990). Boyer envisioned institutions and their faculty to not only respond to the current ills facing society through teaching and research, but also encouraged pressing social issues to be defined by both the academy and its communities to guide the research agenda of engaged faculty (Boyer, 1990). Further, due to the current significance of teaching and research as the primary measuring sticks by which institutions used to gauge faculty productivity and value, Boyer ultimately challenged the academy to rethink what it means to be an academic and a scholar and how scholarly work is prioritized and rewarded within the academy.

Scholarship, he reasoned, requires one to take a more engaged approach to teaching and research in order to benefit the greater good and the "renewal of society itself" (Boyer, 1990, p. 81). Boyer maintained that the failure of the academy to purposefully engage with local communities and actively work to advance shared social concerns should be of the utmost concern for institutions of higher education in the $21^{\text {st }}$ century. To Boyer (1990), the biggest challenge facing higher education was if it was both willing and able to utilize its resources to encourage its faculty to be of greater service to local communities, the nation, and the world (Hill, 2010).

\section{Engaged Teaching and Research}

Throughout his professional career, Boyer sought to contest the assumption that academic work is most valuable when it exists in isolation, disengaged from community, and driven primarily by the needs and interests of faculty. Though it is understood that most all faculty work in some way touches the broader public, the integration of community into the processes of teaching and research (e.g. identifying mutually beneficial goals, collaboratively guiding the research process, etc.) that encourages faculty to leave the ivory tower and engage with local communities is of focus here.

In the mid- $20^{\text {th }}$ century, the concept of the ivory tower became infused with the ideas of academic freedom and social critique; it was understood as an environment free of bias or ideology (Tierney \& Perkins, 2015). Those within the ivory tower, far removed from society, were believed not

Journal of the Scholarship of Teaching and Learning, Vol. 20, No. 2, October 2020. josotl.indiana.edu 
to be easily persuaded by an idea, belief, or relationship to which one might fall victim if they are engaged in the world (Tierney \& Perkins, 2015). Thus, the pure, unencumbered idea of the ivory tower has tended to define the core assumptions of academic life (Boyer, 1990). Though the scholarly products and innovations generated from faculty who work in isolation are many and should be praised for their contributions to society, Boyer and others recognized that to advance institutional/community engagement grounded in the tenets of reciprocity and mutual benefit, institutions must work to equally recognize and reward faculty who choose to engage their teaching and research in and with community.

Segregating academics from the public was understood as logical a century ago, due to the public's expectations of higher education (Tierney \& Perkins, 2015; Votruba, 1996). However, as illustrated by Boyer's (1990) critique, the public's notion of education and its role within society continues to evolve. Led by Boyer, the late $20^{\text {th }}$ century movement calling for institutions to bridge the gap between the academy and the real world and reprioritize the recognition of engaged work has revived the conversation about the fundamental missions of American colleges and universities, and how to align institutional structures and processes, such as promotion and tenure, with the public purpose of higher education (Liang et al., 2015; Plater, 2011).

\section{Faculty Engagement Today}

Nearly thirty years after Boyer's Scholarship Reconsidered, research within the field of higher education community engagement has expanded tremendously. The engagement movement in the late $20^{\text {th }}$ century sparked by Boyer and championed by major professional organizations such as the National Association of State Universities and Land Grant Colleges, the American Association of State Colleges and Universities, and the Kellogg Commission on the Future of State and Land-Grant Colleges brought to the forefront of higher education the need for institutions to revisit their socially-focused roots and value the engaged work of faculty. Following Boyer's (1990) Scholarship Reconsidered, scholars have worked to expand the traditional understanding of faculty work to include engaged teaching and scholarship that emphasizes "bidirectional interactions, reciprocity, and mutual respect" (Byrne, 1998; Ray, 1999; Sandmann, 2008, p. 94; Simpson, 2000).

By the early 2000s, community engagement was beginning to establish itself within both the traditional conceptions of teaching and research while simultaneously working to differentiate itself from other forms of service. Although engaged teaching and scholarship includes facets of traditional research and service, it builds on academic work which is understood to be "homogenous, expert-led, supply-driven, hierarchical, peer-reviewed, and almost exclusively university-based knowledge generation" (Sandmann, 2008, p. 97). Engaged teaching and scholarship, rather, are recognized as transdisciplinary, demand-driven, network-embedded, and grounded in "co-generative theorization" (Deetz; 2008; Liang et al., 2015, p. 235; Sandmann, 2008). Engaged faculty are understood as those who "take moral responsibilities and maintain mutual growth" between their scholarly commitments and their communities (Deetz, 2008; Liang et al., 2015, p. 235). Engagement takes on an additional dimension and serves a larger purpose as engaged faculty address problems that are significant to not only themselves and their institutions, but to their local communities and citizens (Bloomgarden \& O’Meara, 2007; Colbeck \& Drago, 2005; Fear, Rosaen, Foster-Fishman, \& Bawden, 2001).

Though many institutions have publicly committed to baking mutually beneficial, reciprocal engagement with community into their missions and strategic plans, promotion and tenure processes among most institutions continue to be critiqued for disadvantaging the communal, interdisciplinary work of engaged teachers and scholars, often encouraging traditional, siloed work distanced from community (Alperin, Munoz Nieves, Schimanski, Fischman, Niles, \& McKiernan, 2018; O’Meara, 2005; Strand et al., 2003; Ward, 2005). Academic culture continues to prefer the norms of traditional

Journal of the Scholarship of Teaching and Learning, Vol. 20, No. 2, October 2020. josotl.indiana.edu 
teaching and scholarship, and many faculty who pursue engaged work do so on the periphery of their institutions, at risk of not achieving promotion and tenure. Thus, institutions must work to build and refine processes and structures that reward faculty whose scholarship and teaching is engaged with community. As demands for institutional and faculty accountability and relevancy continue to increase, it is imperative to establish an understanding of the value engaged faculty brings to institutions, the academy, their local communities, and the nation as a whole. Faculty work, specifically that which is engaged in community, contributes to the larger mission of higher education and serves the public good, which reflects "the highest aspirations of democratic societies" (Turner, 2015, p. 143).

\section{Engaged Academics: Faculty Identities}

Existing literature examining the role of faculty work as expressed through engaged teaching and scholarship focuses primarily on the institutional influences that encourage or prohibit engaged work, personal characteristics and motivations of engaged faculty, and the professional influences (i.e. discipline, rank, etc.) influencing such work (Doberneck, Glass, \& Schweitzer, 2010; O’Meara, 2005; Saltmarsh, Giles Jr., O’Meara, Ward, \& Buglione, 2009; Wade \& Demb, 2009). The influence of faculty demographics on engaged work is complex, yet imperative to best understand the orientations and identities of those who pursue engaged teaching and research and the ways to best support them (O’Meara, Sandmann, Saltmarsh, \& Giles Jr., 2011; Ward, 2010).

Understandably, faculty enter institutions with different preparation and socialization, career goals, and work experiences that vary based on graduate school, discipline, individual demographics, and appointment types (Aguirre, 2000; Antonio, Astin, \& Cress, 2000; Becher, 1989; Holland, 2005; Schuster \& Finkelstein, 2006). Regarding engaged work, studies have found that women faculty tend to perceive a higher personal commitment to engagement than men, as women faculty are more likely than men (53\% vs. $45 \%)$ to acknowledge that their scholarly work advances the public good (Vogelgesang, Denson, \& Jayakumar, 2010). Additionally, in comparison to their white male colleagues, faculty of color are also more likely to engage in outreach and possess a research agenda involving engaged scholarship (Antonio et al., 2000; O’Meara, 2002).

As far as appointment type, contingent faculty and lecturers have been found to be more likely than tenure-track faculty to be engaged scholars (Antonio et al., 2000; Vogelgesang et al., 2010). This is assumed to be because faculty who are not pressured to achieve tenure have more time and interest in developing relationships with external community partners (Antonio et al., 2000). Lastly, academic disciplines which have been found to produce the greatest number of engaged teachers and scholars include the social and behavioral sciences, business, and health fields, while disciplines with the least amount of faculty pursuing engaged scholarship tend to be the arts, humanities, and math (Glass, Doberneck, \& Schweitzer, 2011; Vogelgesang et al., 2010).

\section{Rewarding Engaged Work}

The rethinking of academic work following Scholarship Reconsidered opened the door to configuring a better understanding of how faculty's engagement is prioritized, recognized, and rewarded in the academy. With this came reconsideration of the faculty's role as it relates to academic teaching and research, institutional structures, and policies that support engagement. Over the last three decades there has been tremendous work by national associations, institutions and their administrations, academic deans, faculty leaders, and national scholars to create change in institutional structures that reward engaged teaching and research (O’Meara, 2005). A handful of campuses have begun using broader definitions of scholarship that include a spectrum of engagement and hundreds of institutions

Journal of the Scholarship of Teaching and Learning, Vol. 20, No. 2, October 2020. josotl.indiana.edu 
throughout the country have adopted Boyer's framework of engagement into their promotion and tenure structures. (Calleson, Jordan, \& Seifer, 2005; O’Meara, 2005). However, this work has reached but a small fraction of institutions within the United States. Regrettably, faculty whose primary work preferences engaged teaching and research often face the risk of being denied promotion, tenure, and institutional advancement (O’Meara, 2005; Saltmarsh \& Wooding, 2016).

Resistance to engagement, specifically engaged research, has deep roots within the culture of higher education. As Saltmarsh et al. (2009) noted, the dominant culture of higher education operates under narrow definitions of research, teaching, and scholarly products and tends to not regard engagement as high priority for faculty. As such, in the current climate of American higher education, there is very little incentive for faculty to pursue engaged teaching and research as it is understood here (Rhoades, 2015). The unfortunate reality is that within most institutions, promotion and tenure processes disadvantage engaged teaching and scholarship of an interdisciplinary, collaborative nature and continue to advance scholarship that is not done in conjunction with community, but rather is more unilateral in nature. (O’Meara \& Rice, 2005; Trower, 2008).

\section{Promotion and Tenure}

Over $95 \%$ of all traditional institutions of higher education in the United States had some form of tenure review by the end of the $19^{\text {th }}$ century (Ellison $\&$ Eatman, 2008). However, by the end of the $20^{\text {th }}$ century, promotion and tenure continues to be structured in similar ways as it had for the last century (Tierney \& Perkins, 2015). Although tenure was initially created to allow faculty to take intellectual risks, by the end of the $20^{\text {th }}$ century, Tierney and Bensimon (1996) found it to have the exact opposite effect. Faculty were found to be risk averse, foregoing deep, engaged work for quick publications that produced minimal findings. The route to obtaining tenure quickly became publish or perish and engaged teaching and scholarship fell to the wayside (Tierney \& Bensimon, 1996). Currently, the harsh reality is that when faculty go up for promotion and tenure their engaged work is hardly mentioned (Boyer, 1996).

As peer-reviewed publications in high-impact journals serve as the primary medium for communication of research findings to other academics, they, in turn, are viewed as the gold standard of faculty scholarly output (Braxton, Luckey, \& Hellend, 2002). The more peer-reviewed publications in high quality journals a faculty member produces, the greater their chances of being promoted and increasing their salary. The positive correlation between traditional research outputs and promotion and tenure has been found to hold across all different types of colleges and universities as well as across different academic disciplines (Fairweather, 1996; Tuckman, 1976). However, research universities in particular prioritize the dissemination of peer-reviewed journal articles that reach the academic community over more locally disseminated work such as policy briefs, technical reports, and new media, intended to reach community audiences (Ward, 2005). Academic journal articles do little to reach local community members and organizations, key stakeholders in engaged research. The most effective methods of scholarly dissemination to reach local community audiences are typically community-based presentations, local media articles, web-based content, and public testimony (Seifer, Wong, Gelmon, \& Lederer, 2009; Sobrero \& Jayaratne, 2014).

As local dissemination in non-traditional outlets is produced far more often by engaged faculty, engaged research and its scholarly outputs fall outside the boundaries of the traditional methods for evaluating scholarship, leading to confusion and dismissal by review committees (Braxton et al., 2002). In their review of promotion and tenure documents across 129 American and Canadian institutions that identified various terms related to traditional and engaged scholarship, Alperin et al. (2018) discovered that traditional outputs were mentioned in $90-95 \%$ of all research, masters, and baccalaureate promotion and tenure guidelines, the most consistently present grouping of terms across

Journal of the Scholarship of Teaching and Learning, Vol. 20, No. 2, October 2020. josotl.indiana.edu 
all institutional types and academic disciplines. This consistency led them to conclude that "if there is one thing that is certain to count towards faculty career progression, it is producing traditional academic outputs" (Alperin et al., 2018, p. 15).

The pressure to produce certain types of outputs is felt by scholars who want to be recognized and rewarded for their engagement. O'Meara, Eatman, and Peterson (2015) found that many engaged faculty express frustration that institutional reward structures have not caught up with the dynamic nature of engaged teaching and research (p. 1). In a study by Weerts and Sandmann (2008), promotion and tenure policies were found to be the strongest barrier in limiting faculty's engagement with community. Further, studies of mid-career, tenure-track faculty have illustrated that most faculty felt as if they could not highlight their engaged work within their institution's promotion and tenure system, due to a fear of negative reactions from colleagues and administrators (Baldwin, 1990; Colbeck \& Warton-Michael, 2006; O’Meara, 2005).

This lack of acknowledgement of faculty engagement in institutional reward structures is alarming, when considering that promotion and tenure continues to serve as one of the foremost ways institutions articulate and make public their values (O’Meara, 2002). Calleson, Jordan, and Seifer (2005) reaffirmed this notion, and acknowledged that "a university's values are most clearly described by its promotion and tenure policy and by the criteria used to evaluate faculty members" (p. 320). Promotion and tenure thus serves as a measuring stick by which colleges and universities illustrate what type of faculty work and outputs are most prioritized at their institution.

It is also important to understand that faculty work and corresponding rewards cannot be divorced from the historical, political, and social context of one's unique institution and the world today. In an era wrought with extensive social, political, and economic transformations in society, both on a local and global scale, the nature of faculty work that institutions choose to prioritize and reward speaks volumes. (O’Meara, 2005). Creating the structures to appropriately recognize and reward faculty work that is embedded in community and seeks to advance the interests of equity, reciprocity, and social justice requires not only the rewording of mission and policies but demands a change within institutional roles and rewards. Efforts to recognize and reward engagement must be reflected in the academic and cultural norms within an institution to create a supportive environment that communicates the values of engaged teaching and scholarship and aligns resources to promote them (Saltmarsh et al., 2009; Weerts \& Sandmann, 2008).

Although current promotion and tenure structures within most institutions do not value engaged teaching and scholarship at the same level as traditional scholarly work and its outcomes (e.g. peer-reviewed publications in high-impact journals that are shared within academic circles), many faculty continue to engage in teaching and scholarship and generate outcomes and resources to be utilized by community audiences (e.g. community-based presentations, local media articles, public testimony, etc.) (Seifer, Wong, Gelmon, \& Lederer, 2009; Sobrero \& Jayartne, 2014). In the late 1990s, the Higher Education Research Institute included a new question to their faculty survey. The question asked if faculty, within the past two years, "collaborated with the local community in research" (Hurtado, Eagan, Pryor, Whang, \& Tran, 2012, p. 77). The results of the 2013-14 faculty survey indicated that $48.8 \%$ of faculty at all undergraduate institutions and $50.4 \%$ of faculty at all public universities were academically engaged in their communities in some capacity (Hurtado et al., 2012). However, even though over half of all faculty acknowledge pursuing engaged teaching and scholarship, very few institutions recognize or reward these activities (Hurtado et al., 2012; Saltmarsh \& Wooding, 2016).

Journal of the Scholarship of Teaching and Learning, Vol. 20, No. 2, October 2020. josotl.indiana.edu 


\section{Advancing Engaged Teaching and Scholarship}

As noted, the ways that faculty engage in community and the outcomes and outputs their engagement produces are many. Much research has been done to understand the various types of faculty engagement. Wade and Demb's (2009) conceptual model of faculty community engagement identified specific activities that often constitute faculty engagement (e.g. service-learning courses, communitybased research, professional service, etc.) and presented a Faculty Engagement Model that outlined the personal, professional, and institutional factors that lead to, discourage, and encourage faculty engagement. Further, additional literature detailing more specific ways faculty today engage in community is vast. Most notably, literature examining service-learning (Bringle \& Hatcher, 2000, 2009; O’Meara, 2003; Ward, 1998), volunteer/public service (Antonio et al., 2000; Jaeger \& Thornton, 2006; Lynton, 1995), and community-based research (Calleson et al., 2005; Colbeck \& WartonMichael, 2006; Strand, 2000) is especially robust.

When considering the types of needed reforms within the academy to ensure the engaged work of faculty is appropriately prioritized and rewarded within not only individual institutions but across the academy as a whole, a few shining exemplars may serve as models for change. Specifically, when seeking to change the recognition of faculty's engaged work within the structures of promotion and tenure, a handful of campuses have taken the leap to reform language within their department-, school-, and/or institution-level guidelines to be more inclusive and accepting of engaged work and its various products and outcomes that fall outside the norms of traditional teaching and research. The University of North Carolina Greensboro (UNCG) is a prime example of promotion and tenure reform. Since the early 2000s, UNCG has worked to establish both institution-wide as well as department-specific promotion and tenure guidelines to include engaged teaching and research (Janke \& Shelton, 2011). UNCG is the first institution in the country to establish promotion and tenure guidelines specific to each academic department relating to engaged scholarship. First revising guidelines at the institutional level and employing a trickle-down effect, UNCG then allowed all 54 departments within the institution to adopt policies within their department-specific guidelines to articulate the meaning of engaged teaching and research based on the department's "individual paradigms, policies, and practices" (Janke \& Shelton, 2011, p. 1).

For example, Section II.B.1 (C) of the University of North Carolina at Greensboro's (2010) University-Wide Evaluation Guidelines for Promotions and Tenure states that faculty are encouraged to pursue, "Community Engaged Research and Creative Activities" that include:

Disseminating community engaged research through public programs and events, conducting and disseminating directed or contracted research, conducting and reporting program evaluation research or public policy analysis for other institutions and agencies, and developing innovative solutions that address social, economic, or environmental challenges. (p. 8)

In addition to reforms to promotion and tenure guidelines, other institutions such as Indiana University-Purdue University Indianapolis (IUPUI) identify faculty's engaged work as a defining attribute of the campus within the university's strategic plan and have outlined a number of actions the institution is taking to "Deepen [their] Commitment to Community Engagement", including "defining[ing] community engagement work as distinct from service, so that it can be explicitly captured and reflected in promotion and tenure guidelines" (IUPUI, 2014, p. 24).

In 2005 IUPUI created the academic title of Public Scholar to recognize faculty who are recruited and hired to carry out public scholarship, defined as "An intellectually and methodologically rigorous endeavor that is responsive to public audiences and public peer review ... [and] emphasiz[es] coproduction of knowledge with community stakeholders" (IUPUI FLC on Public Scholarship, 2016,

Journal of the Scholarship of Teaching and Learning, Vol. 20, No. 2, October 2020. josotl.indiana.edu 
p. 2). In 2015 the IUPUI Faculty Learning Committee on Public Scholarship was created with the purpose of "defin[ing] public scholarship, identify[ing] criteria to assist faculty in documenting their community-engaged work, and work[ing] with Deans and department Chairs in adapting criteria into promotion and tenure materials within school and departmental guidelines" (IUPUI FLC on Public Scholarship, 2016, p.1).

Outside of a specific institutional context, many scholars and national organizations have created a plethora of resources to assist department-, school-, and institution-level committees appropriately evaluate the engaged work of faculty (Campus Compact, 2019; DORA, 2019; Jordan, 2007; Wood, Price, Stanton-Nichols, Hatcher, Hong, Haberski, Silverman, Goodlett, \& Palmer, 2018). These resources coupled with the steps taken by institutional leaders such as UNCG and IUPUI serve as excellent examples for individual institutions and the academy as a whole to follow as they work to implement reform and better reward the work of engaged faculty.

\section{Concluding Thoughts}

In Scholarship Reconsidered Ernest Boyer advocated for institutions of higher education and the faculty within them to place their teaching and research in the larger public context. Boyer proposed a new paradigm of academic work that urged faculty to meaningfully engage with community and actively work to advance shared goals. Still today, scholars often have different understandings of the components of engagement that are heavily influenced by personal beliefs and motivations, the institutions where they are located, and the appointment types they hold (Austin, 2015; Glass et al., 2011; O’Meara, 2005; Vogelgesang et al., 2010; Ward, 2010). However, as Boyer (1990) argued, an overall commitment to the public application of knowledge to current societal problems is at the heart of academic work.

Spurred by Boyer's work in the late $20^{\text {th }}$ century, the academy began to seriously reflect on what it means to be a scholar as well as the institutional structures and policies that would both support and reward engagement. Ultimately, if institutions are going to stay relevant in the social, political, and economic context of the $21^{\text {st }}$ century, the structures that prioritize, reward, and thus define academic work must change to be more inclusive of engaged teaching and research (Tierney \& Perkins, 2015). Until faculty feel as though they can pursue engaged teaching and research without jeopardizing their jobs and status within their institutions, higher education will never fully realize its true public purpose.

\section{References}

Accardi, M. (2018, October). From consciousness to action: The next generation of universitycommunity partnerships. Paper presented at the Coalition of Urban and Metropolitan Universities Conference, Chicago, IL.

Aguirre, A. (2000). Women and minority faculty in the academic workplace. ASHE-ERIC Higher Education Report Vol. 27, No. 6. San Francisco: Jossey-Bass.

Alperin, J. P., Munoz Nieves, C., Schimanski, L., Fischman, G. E., Niles, M. T., \& McKiernan, E. C. (2018). How significant are the public dimensions of faculty work in review, promotion, and tenure documents? Humanities Commons [preprint].

Antonio, A., Astin, H. \& Cress, C. (2000). Community service in higher education: A look at the nation's faculty, The Review of Higher Education, 23(4), 373-397. doi:

$10.1353 /$ rhe. 2000.0015

Austin, A. E. (2015). Philanthropy as motivator and meaning: Reflections on academic work. In G. G. Shaker (Ed.), Faculty work and the public good: Philanthropy, engagement, and

Journal of the Scholarship of Teaching and Learning, Vol. 20, No. 2, October 2020.

josotl.indiana.edu 
academic professionalism (p. 47-61). New York, NY: Teachers College Press.

Baldwin, R. G. (1990). Faculty career stages and implications for professional development. In: Schuster, J. H., and Wheeler, D. W. (eds.), Enhancing Faculty Careers: Strategies for Development and Renewal, Jossey-Bass, San Francisco, CA, pp. 20-40.

Becher, T. (1989). Academic tribes and territories. Milton Keynes, United Kingdom: Open University Press.

Bloomgarden, A. H., \& O’Meara, K. (2007). Faculty role integration and community engagement: Harmony or cacophony? Michigan Journal of Community Service Learning, 13(2), 5-18.

Boyer, E. L. (1990). Scholarship reconsidered: Priorities of the professoriate. Special Report, Carnegie Foundation for the Advancement of Teaching. New York, NY: Jossey-Bass.

Boyer, E. L. (1996). The scholarship of engagement, Bulletin of the American Academy of Arts and Sciences, 49(7), 18-33.

Boyer, P. S. (2014). Ernest L. Boyer's career in the context of post-World War II American education, Christian Higher Education, 13(1), 4-16. doi: 10.1080/15363759.2014.856643

Braxton, J. M., Luckey, W., \& Hellend, P. (2002). Institutionalizing a broader view of scholarship through Boyer's four domains. ASHE-ERIC Higher Education Report, 29(2).

Bringle, R. G. \& Hatcher, J. A. (2000). Institutionalization of service learning in higher education. Journal of Higher Education, 71(3), 273-290.

Bringle, R. G. \& Hatcher, J. A. (2009). Innovative practices in service-learning and curricular engagement, New Directions for Higher Education, (147), 37-46.

Brown University. (2018). Community engagement. Retrieved from https://www.brown.edu/swearer/carnegie/about

Byrne, J. V. (1998). Outreach, engagement, and the changing culture of the university. Journal of Public Service and Outreach, 3(2), 3-8.

Calleson, D. C., Jordan, C., \& Seifer, S. D. (2005). Community-engaged scholarship: Is faculty work in communities a true academic enterprise?. Academic Medicine, 80(4), 317-321.

Campus Compact. (2019). Community engaged scholarship tenure and promotion repository. Retrieved from https:/ /compact.org/tenure-and-promotion-repository/

Chambers, T. C. (2005). The special role of higher education in society: As a public good for the public good. In A. Kezar, T. C. Chambers, \& J. C. Burkhard (Eds.), Higher Education for the public good: Emerging voices from a national movement (pp. 3-22). San Francisco: Jossey-Bass.

Cohen, A. (1998). The shaping of American higher education: Emergency and growth of the contemporary system. San Francisco, CA: Jossey-Bass.

Colbeck, C. L. \& Drago, R. (2005). Accept, avoid, resist: How faculty members respond to bias against caregiving ... and how departments can help. Change, 37(6), 10-17.

Colbeck, C. L., \& Wharton-Michael, P. (2006). Individual and organizational influences on faculty members' engagement in public scholarship. In New directions of teaching and learning (17-26). Hoboken, NJ: Wiley Periodicals, Inc. doi: 10.1002/tl.221

DORA. (2019). Improving how research is assessed. Retrieved from https://sfdora.org/

Deetz, S. (2008). Engagement as co-generative theorizing. Journal of Applied Communication Research, 36(3), 289-297. doi: 10.1080/00909880801272301

Dewey, J. (1927). The public and its problems: An essay in political theory. Pennsylvania State University Press.

Doberneck, D. M., Glass, C. R., \& Schweitzer, J. (2010). From rhetoric to reality: A typology of publicly engaged scholarship. Journal of Higher Education Outreach and Engagement, 14(4), 5-35.

Ellison, J. \& Eatman, T. K. (2008). Scholarship in public: Knowledge creation and tenure policy

Journal of the Scholarship of Teaching and Learning, Vol. 20, No. 2, October 2020.

josotl.indiana.edu 
in the engaged university. Syracuse, NY: Imaging America.

Fairweather, J. S. (1996). Faculty work and public trust: Restoring the value of teaching and public service in American academic life. Boston, MA: Allyn \& Bacon.

Fear, F. A., Rosaen, C. L., Foster-Fishman, P., \& Bawden, R. J. (2001). Outreach as scholarly expression: A faculty-perspective. Journal of Higher Education Outreach and Engagement, 6(2), 21-34.

Giroux, H. A. (2003). Youth, higher education, and the crisis of public time: Educated hope and the possibility of a democratic future. Social Identities, 9(2), 141-168.

Glass, C. R., Doberneck, D. M., Schweitzer, J. H. (2011). Unpacking faculty engagement: The types of activities faculty members report as publicly engaged scholarship during promotion and tenure. Journal of Higher Education Outreach and Engagement, 15(1), 7 29.

Habermas, J. (1989). The structural transformation of the public sphere. Cambridge, MA: MIT Press.

Hill, P. A. L. (2010). Twenty years on: Ernest Boyer, scholarship, and the scholarship of teaching, 1-13.

Holland, B. A. (2005). Institutional differences in pursuing the public good. In Kezar, A., Chambers, T. C. \& Burkhardt, J. C. (eds.), Higher Education for the public good: Emerging voices from a national movement, San Francisco: Jossey-Bass.

Hurtado, S. Eagan, K. Pryor, J. H., Whang, H, \& Tran, S. (2012). Undergraduate teaching faculty: The 2010-2011 HERI faculty survey. Los Angeles: Higher Education Research Institute, University of California-Los Angeles.

IUPUI. (2014). Our commitment to Indiana and beyond: IUPUI strategic plan. Retrieved from https://strategicplan.iupui.edu/media/53cd6883-562b-4f80-b9c1-

$927 \mathrm{c0c4c7fcf/ZEAVVA/StrategicPlanContent/PDF/Our \% 20Commitment} \% 20$ to\%20Indi ana $\% 20$ and $\% 20$ Beyond $\% 20$ August $\% 202014$.pdf

IUPUI Faculty Learning Community on Public Scholarship. (2016a). Public scholarship at Indiana university-purdue university Indianapolis [white paper]. Retrieved August 30, 2017, from IUPUI Center for Service \& Learning: https://scholarworks.iupui.edu/handle/1805/9713

Jacoby, R. (1987). The last intellectuals: American culture in the age of academe. New York, NY: Basic Books, Inc.

Jaeger, A. J. \& Thornton, A. H. (2006). Neither honor nor compensation: Faculty and public service. Educational Policy, 20(2), 345-356.

Janke, E. M., \& Shelton, T. (2011). Community engagement. Received from UNCG community, 1 Mar. 2011, https://communityengagement.uncg.edu/wpcontent/uploads/2014/08/UNCG_Community_Engagement_TermsDefinitions_030111.p df

Jordan, C. (2007). Community-engaged scholarship review, promotion \& tenure package. Peer review workgroup, Community-Engaged Scholarship for Health Collaborative, Community-Campus Partnerships for Health, Retrieved from https://www.ccphealth.org/wp-content/uploads/2017/10/CES_RPT_Package.pdf.

Liang, J. G., Sandmann, L. R., \& Jaeger, A. J. (2015). Community engagement: An expression of faculty philanthropy?. In G. G. Shaker (Ed.), Faculty work and the public good: Philanthropy, engagement, and academic professionalism (p. 231-248). New York, NY: Teachers College Press.

Lucas, C. J. (2006). American higher education. New York, NY: Palgrave Macmillan. Lynton, E. A. (1995). Making the case for professional service. Washington, D.C.: American 
Association for Higher Education.

Newman, F. (1985). Higher education and the American resurgence: A Carnegie Foundation special report. Lawrenceville, NJ: Princeton University Press. Retrieved from https:// files.eric.ed.gov/ fulltext/ED265759.pdf

O’Meara, K. A. (1997). Rewarding Faculty Professional Service, Working paper \#19. Boston, MA: New England Resource for Higher Education.

O'Meara, K. (2002). Uncovering the values in faculty evaluation of service as scholarship, Review of Higher Education, 26(1), 57-80. doi: 10.1353/rhe.2002.0028

O'Meara, K. (2003). Reframing incentives and rewards for community service-learning and academic outreach. Journal of Higher Education Outreach and Engagement, 8(2), 201 220.

O'Meara, K. (2005). Encouraging multiple forms of scholarship in faculty reward systems: Does it make a difference? Research in Higher Education, 46(5), 479-510. doi: 10.1007/s11162005-3362-6

O’Meara, K. Eatman, T., \& Petersen, S. (2015). Advancing engaged scholarship in promotion and tenure: A roadmap and call for reform. $A A C U, 101(3)$.

O’Meara, K. \& Rice, R. E. (2005). (eds.), Faculty priorities reconsidered: Rewarding multiple forms of scholarship. Jossey-Bass, San Francisco.

O’Meara, K., Sandmann, L. R., Saltmarsh, J., \& Giles Jr., D. E. (2011). Studying the professional lives and work of faculty involved in community engagement. Innovative Higher Education, 36, 83-96. doi: 10.1007/s10755-101-9159-3

Plater, W. M. (2011). Collective leadership for engagement: Reclaiming the public purpose of higher education. In J. Saltmarsh \& M. Hartley (Eds.), "To serve a largerpurpose": Engagement for democracy and the transformation of higher education (102-129). Philadelphia, PA: Temple University Press.

Ravitch, D. (1990, January). Education in the 1980's: A concern for 'quality'. Education Week, Retrieved from https://www.edweek.org/ew/articles/1990/01/10/09200009.h09.html

Ray, E. J. (1999). Outreach, engagement will keep academia relevant to twenty first century societies. Journal of Public Service and Outreach, 4(1), 21-28.

Rhoades, G. D. (2015). Professors acting for the public good: Beyond the "new normal" to the academy we choose. In G. G. Shaker (Ed.), Faculty work and the public good: Philanthropy, engagement, and academic professionalism (p. 3-17). New York, NY: Teachers College Press.

Rice, R. E., Saltmarsh, J., \& Plater, W. M. (2015). Reflections on the pubic good and academic professionalism. In G. G. Shaker (Ed.), Faculty work and the public good: Philanthropy, engagement, and academic professionalism (p. 3-17). New York, NY: Teachers College Press.

Rudolph, F. (1977). Curriculum: A bistory of the American undergraduate course of study since 1636, San Francisco, CA: Jossey-Bass.

Saltmarsh, J., Giles Jr., D. E., Ward, E., \& Buglione, S. M. (2009). Rewarding communityengaged scholarship. New Directions for Higher Education, 147, 25-35. doi: 10.1002/he.355

Saltmarsh, J., \& Wooding, J. (2016). Rewarding community-engaged scholarship: A state university system approach. Metropolitan Universities, 27(2), 74-86. doi: 10.18060/21128

Sandmann, L. R. (2008). Conceptualization of the scholarship of engagement in higher education: A strategic review, 1996-2006, Journal of Higher Education Outreach and Engagement, 12(1), 91-104.

Schuster, J. H. Finkelstein, M. J. (2006). The American faculty: The restructuring of academic work and careers. Baltimore, MD: Johns Hopkins University Press.

Seifer, S. D., Wong, K., Gelmon, S. B., \& Lederer, M. (2009). The community-engaged

Journal of the Scholarship of Teaching and Learning, Vol. 20, No. 2, October 2020.

josotl.indiana.edu 
scholarship for health collaborative: A national change initiative focused on faculty roles and rewards. Metropolitan Universities, 20(2), 5-21.

Simpson, R. D. (2000). Toward a scholarship of outreach and engagement in higher education. Journal of Higher Education Outreach and Engagement, 6(1), 7-12.

Sobrero, P. \& Jayaratne, K. S. U. (2014). Scholarship perceptions of academic department heads: Implications for promoting faculty community engagement scholarship. Journal of Higher Education Outreach and Engagement, 18(1), 123-151.

Strand, K. (2000). Community-based research as pedagogy. Michigan Journal of Community Service Learning, 7, 85-96.

Strand, K., Marullo, S., Cutforth, N., Stoecker, R., \& Donohue, P. (2003). Community-based research and higher education. San Francisco, CA: Jossey-Bass.

Thelin, J. (2004). A history of American higher education. Baltimore, MD: Johns Hopkins University Press.

Tierney, W. G. \& Bensimon, E. M. (1996). Promotion and tenure: Community and socialization in the academe. Albany, NY: State University of New York.

Tierney, W. G. \& Perkins, J. F. (2015). Beyond the ivory tower: Academic work in the $21^{\text {st }}$ century. In G. G. Shaker (Ed.), Faculty work and the public good: Philanthropy, engagement, and academic professionalism (p. 185-198). New York, NY: Teachers College Press.

Trower, C. A. (2008). Promoting interdisciplinarity: Aligning faculty rewards with curricular and institutional realities.

Tuckman, H. P. (1976). Publication, teaching and the academic reward system. Lexington, MA: Lexington Books.

Turner, R. C. (2015). Faculty work as philanthropy: Doing good and doing it well. In G. G. Shaker (Ed.), Faculty work and the public good: Philanthropy, engagement, and academic professionalism (p. 141-152). New York, NY: Teachers College Press.

University of North Carolina at Greensboro. (2010). University-wide evaluation guidelines for promotions and tenure. Retrieved from https://drive.google.com/file/d/0B3_J3Uix1B4UZGhreWVPcFI2NWM/view

Veysey, L. R. (1965). The emergence of the American university. Chicago, IL: The university of Chicago Press.

Vogelgesang, L. J., Denson, N., Jayakumar, U. M. (2010). What determines faculty-engaged scholarship? The Review of Higher Education, 33(4), 437-472. doi: 10.1353/rhe.0.0175

Votruba, J. C. (1996). Strengthening the university's alignment with society: Challenges and strategies. Journal of Public Service and Outreach, 1(1), 29-36.

Wade, A., \& Demb, A. (2009). A conceptual model to explore faculty community engagement. Michigan Journal of Community Service Learning, 15, 5-16.

Ward, E. (2010). Women's ways of engagement. Unpublished doctoral dissertation, University of Massachusetts Boston.

Ward, K. (1998). Addressing academic culture: Service learning, organizations and faculty work. In R. Rhoads \& J. Howard (Eds.), Academic service learning: A pedagogy of action and reflection (pp. 73-80). San Francisco: Jossey-Bass.

Ward, K. (2003). Faculty service roles and the scholarship of engagement. ASHE-ERIC Higher Education Report, 29(5), San Francisco, CA: Jossey-Bass.

Ward, K. (2005). Rethinking faculty roles and rewards for the public good. In A. Kezar, T. C. Chambers, \& J. C. Burkhard (Eds.), Higher Education for the public good: Emerging voices from a national movement (pp. 217-234). San Francisco, CA: JosseyBass. 
Weerts, D. J., \& Sandmann, L. R. (2008). Building a two-way street: Challenges and opportunities for community engagement at research universities. The Review of Higher Education, 32(1), 73-106. doi: 10.1353/rhe.0.0027

Wood, E., Price, M. F., Stanton-Nichols, K., Hatcher, J.A., Hong, Y., Haberski, R., Silverman, R., Goodlett, C., \& Palmer, K. L. (2018). Strategies for developing and documenting products of public scholarship in research and creative activity, IUPUI Scholarworks. 